Fordham Law School

FLASH: The Fordham Law Archive of Scholarship and History

Faculty Scholarship

2007

\title{
Constraining Dominant Shareholders' Self-dealing: The Legal Framework in France, Germany, and Italy
}

Pierre-Henri Conac

University of Luxembourg

Luca Enriques

Harvard Law School

Martin Gelter

Fordham University School of Law, mgelter@law.fordham.edu

Follow this and additional works at: http://ir.lawnet.fordham.edu/faculty_scholarship

Part of the Business Organizations Law Commons, International Law Commons, and the Securities Law Commons

Recommended Citation

4 ECFR 491 (2007)

This Article is brought to you for free and open access by FLASH: The Fordham Law Archive of Scholarship and History. It has been accepted for inclusion in Faculty Scholarship by an authorized administrator of FLASH: The Fordham Law Archive of Scholarship and History. For more information, please contact tmelnick@law.fordham.edu. 


\title{
Constraining Dominant Shareholders' Self-Dealing: The Legal Framework in France, Germany, and Italy
}

by

\author{
Pierre-Henri Conac*, Luca Enriques*\%, Martin Gelter***
}

All jurisdictions supply corporations with legal tools to prevent or punish asset diversion by those, whether managers or dominant sharebolders, who are in control. As previous research bas shown, these rules, doctrines and remedies are far from uniform across jurisdictions, possibly leading to significant differences in the degree of investor protection they provide. Comparative research in this field is wrought with difficulty. It is tempting to compare corporate laws by taking one benchmark jurisdiction, typically the US, and to assess the quality of other corporate law systems depending on how much they replicate some prominent features. We take a different perspective and describe bow three major continental European countries (France, Germany, and Italy) regulate dominant shareholders' self-dealing by looking at all the possible rules, doctrines and remedies available there. While the doctrines and remedies reviewed in this article are familiar enough to corporate lawyers and legal scholars from the respective countries, this is less true for many participants in the international discussion, which remains dominated by Anglophone legal scholars and economists. We suggest that some of these doctrines and remedies, namely the German probibition against concealed distributions, the role of minority sharebolders in the prosecution of abus de biens sociaux in France, and nullification suits in all three countries have not received the attention they deserve.

* Professor of Business Law, University of Luxembourg and ECGI (pierre-henri. conac@uni.lu).

$\because$ Professor of Business Law, University of Bologna, and Consob Commissioner (luca. enriques@unibo.it).

$\because \because$ Assistant Professor, Vienna University of Economics and Business Administration, and ECGI (martin.gelter@wu-wien.ac.at).

We wish to thank Georg Eckert, Melvin Eisenberg, Jesse Fried, Jeffrey Gordon, Gérard Hertig, Mathias Siems, and participants to the conference "Enforcement of Corporate Law Rules" held at Harvard Law School on March 30-31 2007, and to the Law and Economics Seminar at the University of California at Berkeley School of Law for precious comments on earlier drafts during various stages of our work on this project. Opinions expressed in this work are exclusively the authors' and do not necessarily reflect those of Consob. 
I. Introduction $\ldots \ldots \ldots \ldots \ldots \ldots \ldots$. . . . . . . . . . . 492

II. Legal strategies against tunneling $\ldots \ldots \ldots \ldots \ldots . \ldots \ldots$

1. Rules on how to enter into self-dealing transactions $\ldots \ldots \ldots 498$

2. Standards: shareholder duties . . . . . . . . . . . . . 500

3. Prohibition against concealed distributions to shareholders . . . . . . . 502

4. Rules and standards against disadvantageous transactions in corporate groups . . 503

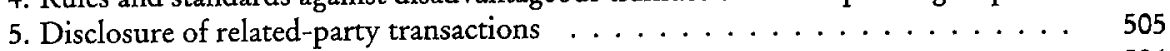

6. Summary . . . . . . . . . . . . . . . . . . . 506

III. Remedies against tunneling . . . . . . . . . . . . . . . 507

1. Liability suits $\ldots \ldots \ldots \ldots$. . . . . . . . . . . . . . . . . 507

2. Appointment of a special auditor ... . . . . . . . . . . 512

3. Nullification of shareholder and board meeting resolutions . . . . . . 513

4. Nullification of conflict of interest transactions $\ldots \ldots \ldots 16$

5. Summary . . . . . . . . . . . . . . . . . . . . 517

IV. Criminal sanctions applicable to tunneling $\ldots \ldots \ldots \ldots$

V. Stock dilution $\ldots \ldots \ldots \ldots \ldots \ldots$

1. Recapitalizations . . . . . . . . . . . . . . . $\quad \ldots \quad 524$

2. Mergers and squeezeouts $\ldots \ldots \ldots \ldots \ldots \ldots \ldots \ldots \ldots$

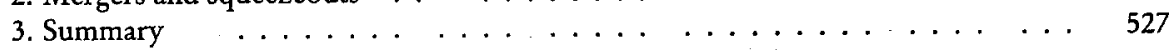

VI. Conclusion: a research agenda $\ldots \ldots \ldots \ldots \ldots \ldots \ldots \ldots \ldots \ldots \ldots$

\section{Introduction}

All jurisdictions supply corporations and their stakeholders with a number of legal tools to prevent or punish asset diversion by those, whether managers or dominant shareholders, who are in control. Fiduciary duties, disclosure provisions, shareholder approval requirements, liability suits, actions to have self-dealing transactions declared void, criminal sanctions and administrative intervention are available, often jointly, to protect the interests of minority shareholders and other stakeholders against insiders' opportunism.

As previous research has shown, these rules, doctrines and remedies are far from uniform across jurisdictions, leading to significant differences in the degree of investor protection that they provide. For instance, Djankov et al. have conducted a comparative study on the regulation of self-dealing based on answers to a questionnaire sent to lawyers from 72 countries. ${ }^{1}$ The quest-

1 Simeon Djankov, Rafael La Porta, Florencio Lopez-de-Silanes \& Andrei Shleifer, 'The Law and Economics of Self-Dealing', December 2005, available at http://ssrn.com/ abstract $=864645$. Their paper draws upon, and updates, the seminal articles written by a partly overlapping group of authors also known as LLSV from the family name initials 
ionnaire contains a number of questions on how the law on the books would treat a hypothetical self-dealing transaction involving a dominant shareholder. In order to conduct an econometric analysis of the correlation between corporate governance law (approximated by the treatment of selfdealing) and finance, they assign scores according to whether jurisdictions impose some procedural steps or disclosure duties and make some remedies available. Using these scores, they build an anti-self-dealing index as a proxy for the quality of corporate law. Even looking at the European Union (EU) only, the dispersion among the $20 \mathrm{EU}$ jurisdictions they cover is consider-

of four of them (see especially Rafael La Porta, Florencio Lopez-de-Silanes, Andrei Shleifer \& Robert W. Vishny, Law and Finance, 106 J. Pol. Econ. 1113 (1998); Rafael La Porta, Florencio Lopez-de-Silanes \& Andrei Shleifer, 'What Works in Securities Laws?', $61 \mathrm{~J}$. Fin. 1 (2006)). The influence of LLSV's work on the literature and the policy debate has only been equal to the amounts of criticism it has drawn. See, most comprehensively, Holger Spamann, 'On the Insignificance and/or Endogeneity of La Porta et al's 'AntiDirector Rights Index' under Consistent Coding', Harvard Law School Olin Fellows' Discussion Paper No. 7, 3/2006; see also Detlev Vagts, 'Comparative company law - The new wave', in Festschrift für Jean Nicolas Druey 595 (Rainer J. Schweizer, Herbert Burkert \& Urs Gasser eds. 2002) (discussing LLSV's antidirector index from a more traditional comparative law perspective); Sofie Cools, 'The Real Difference in Corporate Law between the United States and Continental Europe: Distribution of Powers', $30 \mathrm{Del}$. J. Corp. L. 697, 704-736 (2005) (criticizing the LLSV index for France and Belgium); Mathias M. Siems, 'What Does Not Work in Securities Law: A Critique of La Porta et al.'s Methodology', 16 Int'l. Company \& Comm. L. Rev. 300 (2005) (criticizing LLSV's recent work on securities law, supra, on the grounds of principles of comparative law); Udo C. Braendle, 'Shareholder Protection in the USA and Germany - "Law and Finance" Revisited', 7 German L.J. 257, 265-277 (2006) (re-coding the antidirector index for Germany and the US); Priya P. Lele \& Mathias Siems, 'Shareholder Protection: A Leximetric Approach', 7 J. Corp. L. Studies 17 (2007) (constructing an alternative index for five countries). Djankov et al.'s more recent study (supra) eschews or alleviates some of the problems, but has some of its own. See e.g. Susanne Kalss, 3. Kapitel: Kapitalverfassung, in Die Reform des österreichischen Kapitalgesellschaftsrechts, Verhandlungen des Sechzehnten österreichischen Juristentags, Band II/1 295, 370 n. 232 (Susanne Kalss \& Martin Schauer 2006) (considering it as a severe methodological flaw that Djankov et al.'s study assumes that the hypothetical shareholder engaged in self-dealing is also a director of the firm, which creates a bias in favor of jurisdictions having special rules on conflicts of interest of directors, but misses the point with respect to self-dealing by large shareholders as such); John Armour, 'Enforcement Strategies in UK Company Law: A Roadmap and Empirical Assessment' 16-17, unpublished paper (on file with the authors) (finding a number of errors in Djankov et al.'s coding for private enforcement with reference to the UK, and recalculating a score of 0.625 instead of 0.93 for UK's antiself-dealing index); see also Priya P. Lele \& Mathias M. Siems, 'Diversity in Shareholder Protection in Common Law Countries', J. Institutional Comparisons, March 2007, at 3 (arguing that shareholder protection varies to a high degree even among common law countries). 
able: on a scale from 0 to 1 , scores range from 0.20 for Hungary to 0.93 for the UK. Looking at continental Europe, where dominant shareholders are much more commonly in control of listed corporations and where their selfdealing is thus more relevant to corporate governance, the study finds scores of $0.38,0.28$, and 0.39 for the three main countries (respectively France, Germany, and Italy) (Figure 1).

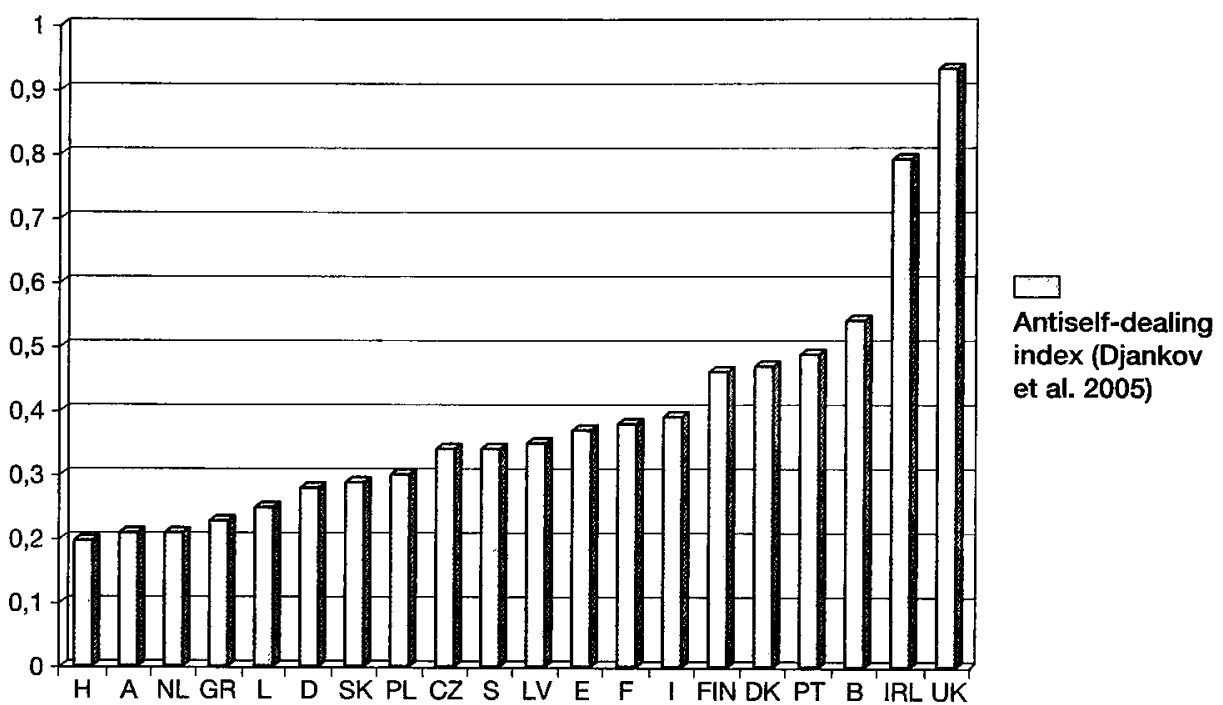

Figure 1. Anti-self-dealing index for EU countries covered by Djankov et al.'s study.

Without doubt, Djankov et al's paper has set a new standard for comparative spadework. With the objective of econometric analysis in mind, the level of functional comparison is necessarily crude. What little we know may also be distorted by an error of perspective that comparative corporate governance scholars risk making. It is in fact tempting to compare corporate laws by taking one benchmark jurisdiction, typically the US, and to assess the quality of other countries' corporate law systems depending on how much they replicate some prominent features of US law, such as for example Delaware Courts' emphasis on approval of self-dealing transactions by a majority of the minority shareholders. ${ }^{2}$ This approach may provide a distorted picture of the effectiveness of other corporate laws, because it might fail to account for legal strategies and enforcement tools that, while unknown to the US corporate governance regime, allow countries to tackle self-dealing differently, but

2 See e.g. Mary A. Jacobson, 'Interested Director Transactions and the (Equivocal) Effects of Shareholder Ratification’, 21 Del. J. Corp. L. 980, 994 (1996). 
no less effectively than the US, or, in other words, to achieve functional as opposed to formal convergence. ${ }^{3}$

This paper describes how three main continental European countries (France, Germany, and Italy) regulate dominant shareholders' self-dealing by looking at all the possible rules, doctrines and remedies available there. We focus on dominant shareholders', as opposed to managerial self-dealing, because it is a well-known fact that in the three countries we consider even the largest listed corporations have often dominant shareholders. ${ }^{4}$ When this is the case, dominant shareholders are in the best position to monitor managers and prevent their opportunism, but they may abuse their power by extracting pecuniary private benefits of control in various ways. While managerial selfdealing and self-dealing by large shareholders overlap, there may sometimes be different legal instruments addressing the two.

Quite apart from outright theft, dominant shareholders can extract pecuniary private benefits, first of all, by entering into contracts with the corporation, whether directly or, more often, through other entities they control (relatedparty transactions). In continental Europe this is often done in the form of intra-group transactions. The dominant shareholder controls a number of companies, both listed and unlisted, and coordinates their businesses at varying degrees. She may have one company pooling cash from the whole group and allocating it according to the liquidity and investment needs of the various group entities. She may have one company providing accounting services to the whole group. She may also allow the whole group to reduce its tax burden by transferring profits from highly profitable companies to ones that

3 This phenomenon might explain some coding mistakes in Diankov et al's recent study (supra note 1). For example, someone familiar with German or Austrian corporate law might notice that the sample transaction in their paper would qualify as a "concealed distribution" (infra section II.2). It is thus mysterious why the rescission variable is coded as 0 for the two countries. Although the authors have not disclosed their questionnaire, the variable definitions lend themselves to the conclusion that local correspondents were misled by questions aiming at an American-style duty-of-loyalty review. See also Lele \& Siems, supra note 1, at 35-37 (finding that protection of minority shareholders against controlling ones is better developed in France and Germany, which are characterized by concentrated ownership, than in the US and the UK).

4 See e.g. Luca Enriques \& Paolo Volpin, 'Corporate Governance Reforms in Continental Europe', 21 J. Econ. Persp. 117, 118-19 (2007). In fact, the empirical evidence shows that dispersed share ownership is prevalent only in two countries, the US and the UK. See Randall K. Morck, 'Introduction, in Concentrated Ownership Structure' 1, 1 (Randall K. Morck ed. 2000); Ronald J. Gilson, 'Controlling Shareholders and Corporate Governance: Complicating the Corporate Taxonomy’, 119 Harv. L. Rev. 1641, 1645-1650 (2006) (both summarizing cross-country evidence). 
lose money via transfer-pricing. ${ }^{5}$ While this kind of coordination may serve legitimate business purposes, each intra-group transaction provides an opportunity for minority shareholder expropriation, especially if it involves companies in which the dominant shareholder owns a different share of cashflow rights, such as one listed company and a wholly owned subsidiary.

Dominant shareholders are often wealthy individuals or families, who might take up a direct role in the management of the companies they control. When this is the case, the shareholders in control, like managers in publicly held companies, might extract private benefits in the form of above-market compensation packages or through perquisites. Following Johnson et al., we use the term "tunneling" to refer to all kinds of transfers of resources out of a company to a dominant shareholder (or a coalition of shareholders jointly dominating the firm) ${ }^{6}$

Further, dominant shareholders can enrich themselves at the expense of minority shareholders by having the corporation approve transactions that, while not involving any sale or purchase by the company, dilute minority shareholders' interests (stock dilution). This is done through mergers with entities also controlled by the dominant shareholders, or by issuing watered stock in their or their associates' favor or by having the corporation buy back their shares at an inflated price.

Since in all of the above cases the dominant shareholder is, personally or through a controlled entity or an associate, on the other side of the relevant transactions with the corporation, we categorize all of these transactions as self-dealing. ${ }^{\top}$

5 Some tax systems create additional incentives to create group structures by permitting the intra-group setoff of profits and losses if the group is closely integrated. For example, under $\$ 14$ of the German Corporation Tax Act (KStG), group members must undertake to transfer all of their profits to the dominant enterprise for a period of at least five years in order to qualify for this privilege.

6 Simon Johnson, Rafael La Porta, Florencio Lopez-de-Silanes \& Andrei Shleifer, 'Tunneling', 90 Am. Econ. Rev. (Proc. Am. Econ. Assoc.) 22, $22-23$ (2000).

7 Self-dealing, even thus broadly defined, of course does not cover all means dominant shareholders have to divert corporate value to themselves. They achieve the same outcome also by trading in the company's shares on the basis of inside information or otherwise exploiting inside information to their own advantage (for the qualification of insider trading as self-dealing see e.g. Robert C. Clark, Corporate Law 145 (1986)), by disseminating false information about the company, in order to raise new equity more cheaply to the detriment of the new shareholders, and by selling their controlling stake to someone else (see Ronald J. Gilson \& Jeffrey N. Gordon, 'Controlling Controlling Shareholders', 152 U. Pa. L. Rev. 785 (2003)). However, we think that self-dealing as we have defined it covers a sufficiently broad array of opportunistic behavior to provide an accurate picture of how the laws constrain dominant shareholders' opportunism in the three sample countries. 
To avoid the perspective error we highlighted above, we have adopted a "domestic" point of view for each of the three sample jurisdictions and drawn up a sort of checklist of rules, doctrines, remedies and provisions that a local practitioner would have to consider in providing advice on a selfdealing transaction by a dominant shareholder and in highlighting legal risks attaching to them.

Our checklist includes: (a) rules specifying whether and how the company may enter into some transactions or take some resolutions; (b) general standards and doctrines that constrain managers' and dominant shareholders' behavior; (c) remedies and actions that a legal system supplies to private parties so as to react to self-dealing transactions; (d) criminal sanctions against selfdealing. Problems of stock dilution are addressed by various sets of mainly rule-based strategies in all three countries, which we address separately in section V.

Our purpose here is simply to provide a complete picture of the variety of available legal tools in the three countries, rather than engaging in an in-depth analysis of each or any of them. Unless otherwise indicated, our description below focuses on public companies (Société anonyme or SA, Aktiengesellschaft or AG, and Società per azioni or Spa). Private limited companies (Société à responsabilité limitée or SARL, Gesellschaft mit beschränkter Haftung or $\mathrm{GmbH}$; società a responsabilità limitata or Srl) typically pose a different set of problems, as minority shareholders are not subject to collective action problems, there are fewer limitations on suits, and because self-dealing is even sometimes an issue addressed in the company's charter.

Of course, the doctrines and remedies we describe are familiar enough to corporate lawyers and legal scholars from the respective countries. This is apparently less true for many economists researching at the intersection of law and finance, and many Anglophone legal scholars engaged in the comparative discussion. Our purpose is to make the wider range of doctrines available in continental Europe more familiar to these audiences, and, in doing so, to highlight core problems of enforcement which appear to interfere with the workings of legal strategies against self-dealing. Our overview shows that all three countries provide a large array of doctrines and remedies against selfdealing. Some of them are different from those familiar to English-speaking scholars and have received little attention in the comparative debate, such as the German prohibition against concealed distributions or the role of minority shareholders in the prosecution of abus de biens sociaux in France. Regarding enforcement, we highlight the importance of nullification suits in all three countries, whereas liability suits remain rare compared to the US, which may be due to certain aspects of continental European procedural law 
The paper proceeds as follows: Section II discusses legal strategies against tunneling, including both ex ante rules and ex post standards, i.e. the doctrines available in the three countries. Section III investigates remedies. We particularly focus on how minority shareholders may challenge a transaction initiated by a large shareholder, and what impediments there may be. Section IV discusses possible consequences under criminal law. Section V discusses rules and standards against stock dilution. Section VI concludes.

\section{Legal strategies against tunneling}

Legal systems may use a variety of strategies to police tunneling, which basically fall into three groups. First, potentially dangerous transactions may require ex ante approval or ex post ratification, e.g. by disinterested directors or shareholders. Second, transactions may be reviewed by a court ex post in the light of a certain standard of conduct. And third, potentially problematic transactions may be subjected to a disclosure requirement, so as to facilitate the ex post evaluation of the firm's position by minority investors. ${ }^{8}$

\section{Rules on bow to enter into self-dealing transactions}

Legal systems often impose procedural requirements as a condition to a selfdealing transaction's validity or anyhow encourage companies to follow a given procedure by making it harder for plaintiffs to challenge procedurally fair transactions. In France, all transactions concerning an SA in which a director or, since 2001, a shareholder with more than 10 percent of the voting rights ${ }^{9}$, or the company controlling such shareholder, has a direct or indirect interest must be authorized ex ante by the board of directors and ratified by the annual shareholder meeting, following a special report by the statutory auditors (commissaires aux comptes)..$^{10}$ The interested party must inform the board of directors about the considered transaction ${ }^{11}$ and abstain from voting both within the board and at the shareholders meeting. ${ }^{12}$ However, these rules do not apply to "current transactions entered into at normal conditions", which only have to be disclosed by the interested party to the chair-

8 But see Henry Hansmann \& Reinier Kraakman, 'Agency Problems and Legal Strategies' 21, 23-24, in The Anatomy of Corporate Law (Reinier Kraakman et al. 2004) (using a fairly different classification).

9 The level was raised from $5 \%$ to $10 \%$ in 2003.

10 Articles L. 225-38 and L. 225-40, French C. Com.

11 Article L. 225-40, French C. Com.

12 Article L. 225-40, French C. Com. 
man of the board, who must then provide a list of such transactions to the board and to the statutory auditors. ${ }^{13}$

French law also prohibits some forms of self-dealing which are deemed to be too dangerous. This is the case of loans to managers or directors or guarantees for their benefit. ${ }^{14}$ However, loans to shareholders, whether individuals or legal entities, are not prohibited.

In Italy, directors have to disclose to other board members and to the members of the board of auditors ${ }^{15}$ any direct or indirect interest they have in any transaction. An indirect interest may well be deemed to exist whenever a dominant shareholder having an interest in a transaction also has influence over a director, ${ }^{16}$ e.g. because the director is also an employee of the parent company ultimately controlled by the dominant shareholder. When it is the $\mathrm{CEO}$ or another executive director who has an interest (direct or indirect) in a transaction that she would have the power to decide on, she has to abstain and request for a board resolution on the transaction. Further, whenever the board decides on a transaction for which an interest has been disclosed or should have been disclosed, it has to provide adequate reasons for entering into the transaction and why the transaction is advantageous to the corporation. ${ }^{17}$

In Germany, while the management board of an AG normally has the authority to enter into contracts on behalf of the company, this is not the case in dealings with any of the board members. The supervisory board represents the company vis-à-vis them..$^{18}$ There are no procedural rules comparable to the French ones addressing transactions with other related

13 Article L. 225-39, French C. Com.

14 Article L. 225-43, French C. Com.

15 Italian companies traditionally have a board of auditors, i.e. a separate organ of the corporation in charge of auditing the company's management. Although the board of auditors has become optional after the 2003 reform, which allows companies to opt into a two-tier, German style, corporate governance structure, or into a one-tier, AngloAmerican style one, most companies have stuck to the traditional structure.

16 Cf. Luca Enriques, 'Il Conflitto d'Interessi degli Amministratori di Società per Azioni' 156-57 (2000).

17 Article 2391, Italian C.c. Prior to the 2003 corporate law reform, disclosure was only required for transaction in which a director had a conflict of interest, but the director also had to abstain from voting on the board resolution relating to the transaction, which is not the case any more. However, these provisions were construed very leniently. See Luca Enriques, 'Do Corporate Law Judges Matter? Some Evidence from Milan', 3 Eur. Bus. Org. L. Rev. 765, 771 (2002).

$18 \$ 112 \mathrm{AktG}$. 
parties. ${ }^{19}$ The courts have been relatively restrictive in their interpretation of the provision described above, and have typically not applied it to other self-dealing situations by analogy (with the exception of cases of "economic identity" between the director and a third party). For example, one court of appeals refused to apply the provision to a situation where one company's director held a significant stake in another firm to which he granted a loan in his capacity as a director of the former. ${ }^{20}$

\section{Standards: sharebolder duties}

In all three jurisdictions, standards are in place that restrict directors' ability to manage the company in the interest of dominant shareholders alone and the ability of dominant shareholders to exercise control powers to the detriment of other shareholders. First, legal scholars and courts hold that directors in all countries owe their company a duty of loyalty that require them to disregard or even oppose dominant shareholders' attempts to selfdeal. ${ }^{21}$ Second, whether implicitly or explicitly, the three countries grant

19 Of course, a transaction can be void under general principles of civil law in cases of collusion (where directors and third parties consciously cooperate to the harm of the firm). See generally Eberhard Schilken, in J. von Staudingers Kommentar zum Bürgerlichen Gesetzbuch $\$ 167$, comments 93 et seq., 100 et seq. (Erstes Buch Allgemeiner Teil, $\$ \$ 164-240,13^{\text {th }}$ ed., Karl-Heinz Gursky, Frank Peters, Eberhard Schilken \& Olaf Werner 1995). Furthermore, $\ 181 \mathrm{BGB}$, under which an agent cannot enter into a transaction with her principal on her own behalf or on behalf of a third party unless permitted to do so, also applies to directors. See Klaus J. Hopt \& Markus Roth, in Großkommentar Aktiengesetz, $\$ 112$, comment 44 (4th ed., $24^{\text {th }}$ installment, Klaus J. Hopt $\&$ Herbert Wiedemann eds. 2005).

20 OLG Saarbrücken, 30.10.2000, 8 U 71/00, AG 2001, $483=$ NZG 2001, 414. The majority shareholder of both firms was a partnership, and both firms shared their office

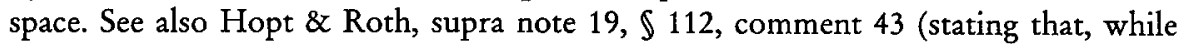
there is universal agreement that $\$ 112$ does not apply to transactions with firms where a director holds a minority stake, the director might have a duty to disclose her conflict of interest to the supervisory board).

21 For Germany, see e.g. Hopt \& Roth, supra note 19, $\$ 116$, comment 181, 184 (stating that a supervisory board member violates her duty of loyalty if acting contrary to the interest of the company and to the benefit of another, even if she also holds a board position there); $\$ 116$, comment 188 (stating that instructions to the contrary must be ignored); $\$ 116$, comment (stating that supervisory board members must leave corporate opportunities to the firm). In France, such a duty has been recognized by case law. The duty of loyalty is owed to the shareholders (Cass. Com. 27 February 1996, JCP éd. E 1996, II, 838, n. D. Schmidt and N. Dion) and to the company (Cass. Com., 24 February 1998, Bull. Joly 1998, p. 913, n. B. Petit. For Italy see e.g. Francesco 
shareholders a right to be treated equally by the corporation, which might prevent it from granting unjustified benefits to its dominant shareholders. ${ }^{22}$ Further, German courts have held that shareholders hold a duty of loyalty to each other. For example, in the seminal Linotype case of 1988, the 96 percent corporate shareholder of an AG had initiated a shareholder resolution to dissolve the firm in order to integrate its profitable business into its own. The Federal Supreme Court nullified that resolution, because it found that the majority shareholder had violated its duty of loyalty by using its voting right to obtain a special advantage to the detriment of the minority. ${ }^{23}$ France and Italy provide for "abuse of majority powers" (abus de majorité in France; abuso della maggioranza in Italy) doctrines that restrict majority shareholders' freedom to vote as they wish at general meetings. In fact, they may not exercise their voting rights in such a way as to pursue their own selfinterest (and not the company's) to the detriment of fellow shareholders. ${ }^{24}$ In France, case law considers that there is an abuse of majority if a majority shareholder votes against the "corporate interest" of the company, in order to pursue her own personal interest and to detriment of the minority shareholders. ${ }^{25}$

Additionally, $\mathbb{1 1 7}$ I of the German AktG provides that a person using her influence on the company to instruct members of the supervisory or management board to act to the detriment of the firm or its shareholders will be liable for damages resulting from this conduct. Until $2005, \$ 117$ VI 1 pro-

Barachini, 'L'appropriazione delle corporate opportunities come fattispecie di infedeltà degli amministratori di s.p.a.', in 2 Il nuovo diritto delle società. Liber Amicorum Gian Franco Campobasso 605, 605-06 (Pietro Abbadessa \& Giuseppe B. Portale eds.) (2006). See also Cass. 24 August 2004, No. 16707 (for the first time explicitly recognizing the existence of a duty of loyalty).

22 This is made explicit by Art. 42 of the Second Directive; $\$ 53$ a AktG; Art. 1832 French C. civil. For Italy see Article 92, Legislative Decree 1998, No. 58 (for listed companies). For non-listed companies there is no explicit provision. But legal scholars tend to recognize that such is a principle valid also for them. See Carlo Angelici, Parità di trattamento degli azionisti, 1987/I Rivista di Diritto Commerciale 1, passim.

23 BGH 1.2.1988, II ZR 75/87, BGHZ 103, 185; see also BGH 22.6.1992, II ZR 178/90, NJW 1992, 3167 (discussing the duty of loyalty in the context of a capital increase).

24 For Italy see e.g. Fabrizio Guerrera, 'Abuso del voto e controllo "di correttezza" sul procedimento deliberativo assembleare', 2002 Rivista delle Società 181, passim. For France, see e.g. J.-P. Legros, 'La nullité des décisions de sociétés', Rev. sociétés, 1991, $\mathrm{n}^{\circ}$ 42, 297; J.-P. Sortais, Abus de droit (Majorité, minorité, égalité), Encyclopédie Dalloz droit des sociétés (2003).

25 See e.g., B. Lecourt, Cass. Com. $1^{\text {st }}$ July 2003, Société Mécano soudure c/ Antoine Balice, Rev. sociétés 2004, p. 337. For shareholders' conflicts of interests in the general meeting under Italian law see infra note 95. 
vided an exemption for those cases where a shareholder had used its voting power in the shareholder meeting to instruct the company's representatives. ${ }^{26}$ Currently, exemptions apply only when the company is part of a contractual group or when it has been integrated into its $100 \%$ parent firm under $\$ 319$ AktG. ${ }^{27}$

\section{Probibition against concealed distributions to shareholders}

German law also deals with self-dealing between the dominant shareholder and the corporation by qualifying such transactions, whenever its economic terms are unfair to the corporation, as concealed distributions. $₫ 57 \mathrm{AktG}$ provides that capital contributions may not be repaid to shareholders. During the life of the company, only accounting profits may be distributed among them. ${ }^{28}$ It may surprise that a doctrine related to legal capital, which is under attack as an inefficient mechanism of creditor (and not shareholder) protection, ${ }^{29}$ might serve a useful purpose for the protection of minority shareholders. However, the basic idea of the doctrine, which has a long pedigree in case law going back to the 1920s, is quite simple: whenever a corporation enters into a transaction with a shareholder (or a related party) on unfavorable terms, this constitutes a de facto distribution to that shareholder. In an $A G$, such a transaction is illegal irrespective of how much equity capital the company actually has, since all distributions must take the form of a dividend. ${ }^{30}$

26 The exemption's interaction with the shareholder's duty of loyalty was not entirely clear. See Michael Kort, in Großkommentar Aktiengesetz, supra note 19, $\$ 117$, note 239; BGHZ 129, 136, 158 et seq.

$27 \$ 117$ VII AktG. In the former case, shareholders are entitled to compensation. See infra section V.2.

$28 § 57$ III AktG.

29 See John Armour, 'Share Capital and Creditor Protection: Efficient Rules for a Modern Company Law', 63 Modern L. Rev. 355 (2000); Luca Enriques \& Jonathan R. Macey, 'Creditors versus Capital Formation: The Case Against the European Legal Capital Rules', 86 Cornell L. Rev. 1165, 1185-88 (2001); Peter O. Mülbert \& Max Birke, 'Legal Capital - Is There a Case Against the European Legal Capital Rules?', 3 Eur. Bus. Org. L. Rev. 695, 732 (2002).

$30 \$ 57$ III AktG. By contrast, a $\mathrm{GmbH}$ is only allowed to make distributions to share-

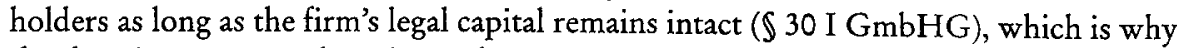
the doctrine comes to bear in $\mathrm{GmbH}$ typically only in insolvency situations. Clawback from shareholders is only possible within a period five years in AGs and within 10 years in GmbHs ( $\$ 62$ III AktG, $\$ 31 \mathrm{~V} \mathrm{GmbHG)}$ and is ruled out by good faith of

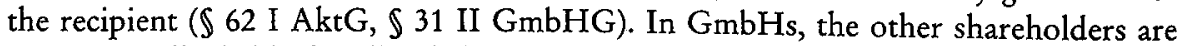
proportionally liable for illegal distributions, with a limitation period of five years

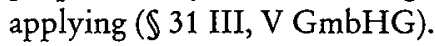


No such doctrine has received any considerable attention in Italy ${ }^{31}$ or in France. ${ }^{32}$ In both countries, like in Germany, though, in line with the Second directive, special rules on share buy-backs are in place. ${ }^{33}$

\section{Rules and standards against disadvantageous transactions in corporate groups}

German law is known for its special rules on corporate groups that were introduced in the 1965 reform. It distinguishes between contractual groups and de facto groups. A contractual group is created by a control agreement, under which instructions to the controlled firm become permissible even if they are to the benefit of the controller or other firms within the group. ${ }^{34}$ Hence, the creation of a contractual group - which is normally motivated by tax considerations - is an issue of stock dilution akin to a parent-subsidiary merger, which is why we discuss it in section V.2.

By contrast, an AG may be subject to the law on de facto groups without an agreement by virtue of being under the control of a controlling undertaking. Group law does not apply if the controller is not an undertaking, the definition of which is not entirely clear. ${ }^{35}$ Individuals who are not as such engaged in business are not included in the definition. However, the controlling undertaking need not be another corporation.

In a de facto group, the controlling undertaking may not instruct a controlled firm to enter into disadvantageous transactions unless any disadvantages are compensated for; the compensation must be determined in the same financial year at the latest. ${ }^{36}$ The management board of the controlled company is required to prepare a report on relations with other group firms within the first three months of the year, in which all intra-group transactions of the firm are

31 Cf. Massimo Miola, 'Legal Capital Rules in Italian Company Law and the EU Perspective, in Legal Capital in Europe', ECFR Special Volume No 1, 515, 528 (Marcus Lutter ed. 2006).

32 Cf. Holger Fleischer, 'Disguised Distributions and Capital Maintenance in European Company Law, in Legal Capital in Europe', ECFR Special Volume No 1, 94, 102-05 (Marcus Lutter ed. 2006) (describing the formalistic understanding of distributions in France).

33 For France see, Articles L. 225-207 to L. 225-217, French C. Com.; for Germany see IS 71-71e AktG; for Italy, see Article 2357-2359-quater, Italian C.c., and Article 132, Legislative Decree No. 58 of 24 February 1998.

$34 \$ 308$ AktG.

35 See Karsten Schmidt, Gesellschaftsrecht 935-939, 1212-1214 (4 $4^{\text {th }}$ ed. 2002).

$36 \$ 311 \mathrm{AktG}$. 
described and compensation received is discussed. This "dependency report" (Abhängigkeitsbericht) must be audited by the statutory auditor and the supervisory board, which reports to the shareholder meeting. ${ }^{37}$ The requirements for the appointment of a special auditor are relaxed if the statutory auditor or the supervisory board found irregularities or if the management board itself declares that disadvantageous transactions were not compensated for. ${ }^{38}$

Notably, the requirements for derivative suits by the shareholders of the controlled entity are relaxed in corporate groups. ${ }^{39}$

At least since the 1980s, Italian legal scholars have pointed out that the harm caused by one single intra-group transaction might find compensation in other transactions or group relationships, whether past or future (the socalled "teoria dei vantaggi compensativi" or theory of compensatory group advantages).$^{40}$ Courts have tended to uphold such a theory in the last two decades. ${ }^{41}$

Mainly following such scholarly and case-law developments, the 2003 corporate law reform has for the first time provided for specific rules on integrated groups and intra-group transactions, basically recognizing that controlled companies can be managed as a division of a group-integrated business. At the same time, it introduced procedural rules to be followed in intra-group transactions, together with an obscure standard for the ex post review of the overall fairness of managerial decisions within the group to minority shareholders and creditors. On the one hand, subsidiaries have to provide an "analytical justification" of transactions that are entered into under the influence of the parent company, by specifying the reasons and the interests that have been considered in deciding to enter into them. Further, account of such transactions must be given in the annual report. On the other hand, minority

$37 \$ 313,314$ AktG. Note that shareholders do not have access to the dependency report.

$38 \$ 315$ AktG. Infra section III.2.

39 Infra section III.1.

40 See e.g. Berardino Libonati, 'Gli atti compiuti dalla società controllata a favore della società controllante', 1989 Rivista di diritto commerciale, II/220; Paolo Ferro-Luzzi \& Piergaetano Marchetti, 'Riflessioni sul Gruppo Creditizio', 1994 Giurisprudenza commerciale, I/419, I/453-54; Paolo Montalenti, 'Conflitto di interesse nei gruppi di società e teoria dei vantaggi compensativi', 1995 Giurisprudenza commerciale, I/710, I/731-32.

41 See Vincenzo Cariello, "The "Compensation" of Damages with Advantages Deriving from Management and Co-ordination Activity (Direzione e Coordinamento) of the Parent Company (Article 2497, Paragraph 1, Italian Civil Code)', 3 Eur. Comp. \& Fin. L. Rev. 330, 331 (2006) for references. See also Enriques, supra note 17, at 796 for a summary of two Milan court cases applying the group defense. 
shareholders of subsidiary corporations can sue the parent company and its directors for pro rata damages suffered qua shareholders if the parent, according to the convoluted wording of a new Civil Code provision, "in carrying out its activity of management and co-ordination of the group, acts in its own or others' business interests in violation of the principles of correct company and business management". However, the parent "shall not be held liable when the damage is lacking in light of the overall results of the management and co-ordination activity or when the damage has been entirely eliminated, possibly through transactions specifically aimed at such purpose." 42

In France, a few special rules on intra-group transactions apply, but no general or partial regime like in Germany and in Italy can be found in the statutes. For instance, the law allows loans to directors that are legal entities, while it prohibits them when granted to directors who are natural persons. ${ }^{43}$ Further, a special provision allows cash pooling within groups, which otherwise would be prohibited by banking laws to businesses other than banks. ${ }^{44}$ While there are no other special rules that allow treating intra-group transactions less severely than other forms of self-dealings who are natural persons, within the context of criminal law, French courts have developed the Rozenblum doctrine that allows a "group defense." 45

\section{Disclosure of related-party transactions}

The three countries also provide for "per se" disclosure of self-dealing transactions, i.e. quite apart from the procedural rules that have to be followed in order to enter into them. Following EC provisions on annual accounts, Italian, German and French accounting rules require that individual annual accounts contain a separate indication of credits toward and shares held in affiliated undertakings ${ }^{46}$ and undertakings with which the company is linked

42 Article 2497, Italian C.c.

43 Article L. 225-42 French C. Com.

44 Article L. 511-73; French Monetary and Financial Code.

45 Infra section III.5. Cf. also Maggy Pariente, "The Evolution of the Concept of "Corporate Group" in France', ECFR, Vol. 4, 2007, p. 317.

46 Affiliated undertakings are defined in Art. 41 of the Seventh Directive, which refers to Art. 1, which sets out a complex definition when a firm must be included in consolidated accounts. In other words, "affiliated undertakings" are all corporations which must be included in one set of consolidated accounts by virtue of having a common controlling or parent company. See $\$ 271$ II HGB, Article L. 233-16 French C. com., and Article 2359 Italian C.c. 
by virtue of participating interests, ${ }^{47}$ together with debts toward the same entities and, in Italy, shareholders in general..$^{48}$ Of course, listed companies in all three countries have to draw up their consolidated accounts according to International Financial Reporting Standards (IFRS) since $2005,{ }^{49}$ so that IAS 24 on related party transactions applies to them. ${ }^{50} \mathrm{~A}$ recent directive that has yet to be implemented in the Member States has amended the EC Accounting Directives to require extensive disclosures about material related party transactions that "have not been concluded under normal market conditions," and refers to IFRS with respect to the definition of the term "related party." "51

Since 2002, Italian listed companies are required to disclose material relatedparty transactions on an ongoing basis. ${ }^{52}$

\section{Summary}

While the basic framework of legal strategies against self-dealing is quite similar in the three jurisdictions, there are some notable differences. The law is quite similar regarding disclosure requirements, which have been implemented under the influence of EC law and International Financial Reporting Standards (section II.5.), and the general standard of conduct for large shareholders (section II.2.). However, France and Italy rely on ex ante approval requirements to a larger degree than Germany (section II.1.). Germany, on the

47 Art 17 of the Fourth Directive defines a participating interest as "rights in the capital of other undertakings, whether or not represented by certificates, which, by creating a durable link with those undertakings, are intended to contribute to the company's activities". Member states may set a threshold not exceeding $20 \%$ beyond which a participating interest is presumed. German law sets that presumption at $20 \%$ ( $\$ 271$ I HGB), Italian law generally at $20 \%$, but only at $10 \%$ in the case of an interest in a listed company (Article 2359(3), Italian C.c.); French law sets that presumption at 10 percent, regardless of whether the company is listed or not (Article L. 233-2, French C. Com.).

48 Article 2424, Italian C.c.; $\$ 266$ HGB; Article L. 123-13 to L. 123-15, French C. Com.

49 Regulation (EC) No. 1606/2002, 2002 O.J. (L 243) 1.

50 IAS 24 was endorsed by Commission Regulation (EC) No 2238/2004 of 29 December 2004, OJ L 394/1 (2004).

51 Article 43(1)(7b) Fourth Directive and Article 34(7b) Seventh Directive, as amended by Directive 2006/46/EC of the European Parliament and of the Council of 14 June 2006, 2006 O.J. (L 224) 1.

52 See Article 71-bis, Consob Regulation on Issuers (available at http://www.consob.it/ mainen/documenti/english/laws/reg11971e.htm). Materiality is defined as occurring when the transactions, "for their contents, consideration, conditions or time of execution may have an impact on a company's solvency or on the completeness and faithfulness of available information pertaining to the issuer". 
other hand, has an additional standard of conduct in the guise of the doctrine of "concealed distributions" (section II.3.). Furthermore, Germany and Italy have an additional level of detailed provisions addressing corporate groups, which combine a standard-based approach and reporting requirements (section II.4.).

\section{Remedies against tunneling}

Legal strategies against tunneling are of course pointless without appropriate remedies and enforcement mechanisms. Besides liability suits as the remedy most obvious to Anglophone readers, we consider suits to nullify conflicted transactions and shareholder resolutions. We also describe other minority rights that may facilitate suits or give bargaining power to minority shareholders.

\section{Liability suits}

While in France individual shareholders have traditionally been able to sue directors on behalf of the corporation (action sociale ut singuli), ${ }^{53}$ at least until recently this has been far more difficult in Germany and especially in Italy. Before 2005, in German AGs only a shareholder holding $5 \%$ or at least an amount of shares corresponding to $€ 500.000$ in par value could petition a court to appoint a representative to bring a suit on behalf of the company if the shareholder meeting had decided not to authorize a liability suit. ${ }^{54}$ Under the new provisions, a 1 percent or a $€ 100,000$ holding (again in par value) is enough, ${ }^{55}$ while a special "lawsuit admission procedure" (Klagezulassungsverfabren) was introduced to screen out abusive suits. Among other things, plaintiff shareholders must show that the firm failed to bring a suit within a reasonable period upon a demand by shareholders. The court must then decide whether there are indications that the company suffered damages from dishonesty or from serious violations of the law or the charter, and whether a suit would be contrary to the preponderating interest of the company. ${ }^{56}$

53 Article L. 225-252, French C. com.

$54 \int 147$ III AktG (before 2005).

$55 \$ 148 \mathrm{I} \mathrm{AktG}$, as amended by the Gesetz zur Unternehmensintegrität und Modernisierung des Anfechtungsrechts (UMAG), of September 22, 2005, BGBl. I 2005, No. 60., p. 2802 (Sept. 27, 2005).

$56 \$ 148 \mathrm{II} \mathrm{AktG}$, as amended by the UMAG, supra note 55 . 
The requirements for derivative suits are easier to meet under the law of corporate groups ${ }^{57}$ In a de facto group, the controlling entity is liable to the controlled corporation if it instructed the controlled entity to enter into a disadvantageous transaction without providing compensation by the end of the fiscal year or granting a legal title to claim compensation. Managers of the controlling entity are jointly and severally liable. ${ }^{58}$ Other than in the case of regular derivative suits against managers, such a suit may be brought by any individual shareholder, without a specific percentage limit. The law also limits the possibility of settlements. ${ }^{59}$ Members of the management and supervisory boards of the controlled corporation may also be liable. ${ }^{60}$

In Italy, derivative suits were first allowed in 1998 for listed companies only, and standing to sue was granted to shareholders owning at least 5 percent of the shares (2.5 percent since 2006; bylaws can provide for a lower threshold). The 2003 corporate law reform made derivative suits available to shareholders in unlisted corporations, but restricted it to those owning at least 20 percent of the shares (bylaws can provide for a lower threshold or for a higher one, up to one third of the shares). ${ }^{61}$ Similar to Germany, individual shareholders of subsidiaries in a group have a special action for damages suffered pro rata qua shareholders in case of group mismanagement. ${ }^{62}$

As a consequence of the threshold for standing to sue in derivative suits ${ }^{63}$ and other hurdles to shareholder litigation ${ }^{64}$ in Germany and Italy liability suits against directors have always been rare (even in the case of corporate groups). Most often, they were brought by the company after a change in control or by the bankruptcy trustee after the company had gone bankrupt. One should note, however, that even in France derivative suits have been fairly rare, ${ }^{65}$ likely due to the absence of the procedural rules (on discovery, legal fees, and

57 Supra section II.4.

$58 \$ 317$ III AktG.

$59 \$ 309$ III, IV AktG and $\$ \$ 310$ IV, 317 IV and 318 IV AktG (all referring to $\$ 309$ III to $\mathrm{V})$.

$60 \$ 318$ AktG.

61 Since 2004 any Srl shareholder can sue directors for damages on behalf of the corporation. See Article 2476, Italian C.c.

62 See supra text preceding note 42.

63 See Kristoffel R. Grechenig \& Michael Sekyra, 'No Derivative Shareholder Suits in Europe - A Model of Percentage Limits, Collusion and Residual Owners', available at http://ssrn.com/abstract=933105 (modeling how percentage limits destroy incentives to bring derivative suits).

64 See generally Luca Enriques, 'The Comparative Anatomy of Corporate Law', 52 Am. J. Comp. L. 1011, 1023-24 (2004).

65 See Yves Guyon, Droit des affaires - Droit commercial général et Sociétés, Tome 1, $n^{\circ} 462$, p. 506, 2003 (stating that the "action sociale ut singuli" is rarely exercised). 
pleading) that are needed for a plaintiff bar to prosper. ${ }^{66}$ Among these, the ban on contingency fees has often been identified as a main hurdle to shareholder litigation. ${ }^{67}$ While France still retains the ban, Germany is in the process of allowing contingency fees and Italy has recently done so. ${ }^{68}$ It remains to be seen whether these prospective or recent changes in German and Italian laws will spur shareholder suits.

Furthermore, with the exception of the German and Italian laws of corporate groups described before, derivative suits against shareholders are not normally admissible. ${ }^{69}$ However, under Italian and French laws, liability suits can be brought not only against directors formally elected, but also toward anyone de facto managing the company by exercising powers that are typical of a director, like presiding over board meetings, individually making the main company's decisions, and so on. ${ }^{70}$ Typically, this can be the case of a

66 See Enriques, supra note 64, at 1023-24.

67 See ibid.

68 The German Bundesverfassungsgericht (Federal Constitutional Court) recently declared the current outright prohibition against contingency fees to be unconstitutional, as it did not take into account that under certain circumstances contingency fees may facilitate the prosecution of legal claims. BVerfG 12.12.2006, 1 BvR 2576/04, NJW 2007, 979. The legislature must amend the law to take the decision into account by June 30, 2008. Italy abolished the ban on contingency fees in July 2006. See Art. 2(1)(a) of Decree Law 4 July 2006, No. 223, (G.U. 4 July 2006, No. 153), as modified by Law 4 August 2006, No. 248 (G.U. 11 August 2006, No. 186).

69 See Wolfgang Zöllner, 'Die sogenannten Gesellschafterklagen im Kapitalgesellschaftsrecht', 17 Zeitschrift für Unternehmens- und Gesellschaftsrecht 392, 407-411 (1988).

70 In French law, de facto directors and managers (dirigeants de faits) of solvent companies are subject to liability not pursuant to the specific provisions of the commercial code regarding liability, since they do not include de facto managers, but rather under general tort principles (Article 1382, French civil code). See Cass. com., 21 March, 2005, Rev. Sociétés 1995 , p. 501 , n. B. Saintourens. When the company is insolvent, de facto directors and managers are subject to liability pursuant to specific provisions of the French commercial code (Article L. 652-1, French C. com.). For Italy see e.g. Trib. Milano, 11 September 2003, 2003 Diritto e Pratica delle Società, No. 23, 74. German law has developed a doctrine of de facto managers ("faktischer Geschäftsführer"), who are subject to certain duties (e.g. to file for insolvency), but it is disputed and unclear how far these duties reach and whether provisions on derivative suits apply. See. e.g. Holger Altmeppen, in Gesetz betreffend die Gesellschaften mit beschränkter Haftung ( $G m b H G), \$ 43$, comment 69 ( $5^{\text {th }}$ ed., Günter H. Roth \& Holger Altmeppen eds.); see also Susanne Kalss, Nikolaus Adensamer \& Janine Oelkers, 'Director's Duties in the Vicinity of Insolvency - a comparative analysis with reports from Germany, Austria, Belgium, Denmark, England, Finland, France, Italy, the Netherlands, Norway, Spain and Sweden, in Legal Capital in Europe', ECFR Special Volume No 1, 112, 115 (Marcus Lutter ed. 2006). Cf. also $\$ 117$, discussed supra in notes $26-27$ and accompanying text. 
dominant shareholder. ${ }^{71}$ Other than that, the widely held view among Italian legal scholars is that, outside the context of groups ${ }^{72}$ majority shareholders are not liable for damages stemming from the latter's behavior qua shareholders, such as for voting in favor of shareholder meeting resolutions harming minority shareholders. ${ }^{73}$ Further, if the dominant shareholder's behavior has harmed the corporation, a court would deny minority shareholders' standing to sue derivatively, because, other than when the law so explicitly provides, derivative actions can only be brought by creditors, and shareholders as such are held to be no creditors of their corporations. ${ }^{74}$ On its face, French law is friendlier to minority shareholders than Italy's. The controlling shareholder can be held liable towards the minority shareholder if she acted with the intention to harm (intention de nuire). ${ }^{75}$ The standard, however, is very demanding and plaintiff shareholders seldom win such cases.

Shareholders in all the three countries can also sue directors if they suffer damage qua individuals or qua investors as opposed to qua shareholders, although only under special circumstances in France and Germany. This is especially the case in the event of securities fraud, which might also take place by omitting to inform the public, or by providing false information, on selfdealing transactions. However, while in Italy negligence is enough to hold directors liable ${ }^{76}$ for a direct claim against a director German law requires to establish either the violation of a protective statute, such as a provision of

71 See e.g. Niccolò Abriani, 'Gli Amministratori di Fatto delle Società di Capitali' 76 (1998).

72 See infra, text preceding note 149.

73 See Roberto Sacchi, 'Tutela Reale e Tutela Obbligatoria della Minoranza', in 2 Il nuovo diritto delle società. supra note 21,135, at 163-65. But see Fabrizio Guerrera, 'La Responsabilità "Deliberativa" nella Società di Capitali' 290-91 (2004) (arguing on doctrinal grounds that dominant shareholders may be held liable toward minority shareholders for abuse of voting powers).

74 See e.g. Federico M. Mucciarelli, 'L'Azione Sociale di Responsabilità Contro gli Amministratori di Società Quotate', 27 Giurisprudenza Commerciale 59, 71-76 (2000).

75 Cass. Com. 13 March 2001, Bull. civ. IV, n 60, D. 2001.1175, obs. A. Lienhard, Dr. sociétés 2001, n 101, obs. F. X. Lucas, Rev. Sociétés 2001, p. 818, n. B. Dondero, Bull. Joly 2001.891, n. C. Prieto, JCP, éd. E, 2001.953, n. A. Viandier, RTD com. 2001.443, obs. C. Champaud et D. Danet. In this last case, two shareholders have been held liable for having dismissed the manager of a limited liability company (SARL). The legal reasoning is applicable to a suit in a SA. See also with a similar fact pattern, Cass. com. 22 November 2005, Rev. Sociétés 2006, p. 526, n. L. Godon.

76 See Article 2395 Italian C.c. See also Franco Bonelli, Gli amministratori di s.p.a. dopo la riforma delle società 215-22 (2004) (citing the case of damages following trade of securities in the presence of false annual accounts as the typical case of a direct liability suit against directors). 
criminal law, or proof of intent. ${ }^{77}$ Similarly, in France directors and managers can be held liable for such damages only within a criminal proceeding because under civil law, except in rare circumstances, only the company itself can be sued for false or omitted information. ${ }^{78}$ Finally, in the context of corporate law, the German law on de facto groups explicitly stipulates that the controlling entity is directly liable to minority shareholders if these incurred an individual damage that does not just reflect a lower share value because of a damage to the company. ${ }^{79}$

In France, in the case of an insolvent company, a de jure or de facto director or manager can be held liable, partially or totally, for the debts of a company subject to a liquidation procedure (obligations aux dettes), if the insolvency results, inter alia, from the fact that she used the assets of the company as her own, ${ }^{80}$ abused corporate assets for her own interest, ${ }^{81}$ or misappropriated all or part of the debtor's assets. ${ }^{82}$ Further, a de jure or de facto manager can be subject to personal bankruptcy (faillite personnelle) for having misappropriated all or part of the company's assets. ${ }^{83}$

In Italy, bankruptcy trustees may sue directors and de facto directors and managers for damages stemming from violation of their duties toward the corporation and/or toward creditors. ${ }^{84}$ Similarly, in Germany directors are liable in tort if they (culpably) fail to file for bankruptcy when the company is insolvent or overindebted. ${ }^{85}$

$77 \iint 823 \& 826$ BGB. See e.g. Eckart Gottschalk, 'Die persönliche Haftung der Organmitglieder für fehlerhafte Kapitalmarktinformation de lege lata und de lege ferenda', 2005 Der Konzern 274, 276-278; BGH 19.7.2004, II ZR 402/02, NJW 2004, 2971; see also Susanne Kalss, 'Recent developments in liability for nondisclosure of capital market information', 27 Int'l Rev. L. \& Econ. 70, 90-91 (2007); see also BGH 4.6.2007, II ZR 147/05, AG 2007, 620 and II ZR 173/05, AG 2007623 (each rejecting a fraud-onthe-market theory and requiring investors to show causality between disclosure of false information and specific investment decision).

78 See generally Charles Arsouze \& Patrick Ledoux, 'L'indemnisation des victimes d'infractions boursières', Bull. Joly Bourse 2006, $\mathrm{n}^{\circ} 4$, p. 399. Since 2003 there have been several court suits against listed companies which have been successful.

$79 \$ 317$ I AktG.

80 Article L. $652-11^{\circ}$, French C. com.

81 Article L. $652-12^{\circ}$, French C. com.

82 Article L. $652-13^{\circ}$, French C. com.

83 Article 653-3, French C. com. Before the 2006 reform, former Article L. 625-3, French C. Com.

84 Article 2394-bis, Italian C.c. Article 2394 of the Italian Civil Code generally makes directors liable toward creditors for violation of "duties relating to the preservation of a company's assets integrity", such as duties stemming from legal capital rules.

85 See $\$ 92$ II AktG (setting forth the requirement to file for bankruptcy). It is controversial whether this duty also applies to de facto directors. Kalss et al, supra note 70, at 115. 
Of course, the proceeds from all such suits will be distributed, together with the proceeds from liquidation and other suits, first among creditors and then, if these are paid in full, to shareholders pro rata. ${ }^{86}$ In Germany and Italy creditors with claims resulting from a transaction after the time when directors would have been required to file for bankruptcy have a claim to full compensation against directors, which they must pursue on their own. ${ }^{87}$

\section{Appointment of a special auditor}

French law provides that shareholders representing at least 5 percent of the capital (10 percent until a 2001 reform) may, after having submitted a written question and received an unsatisfactory explanation, petition the court for the appointment of a business expert (expert de gestion) in order to gather information about business decisions. ${ }^{88}$ Since these business decisions can sometimes be motivated by directors' self-interest, appointment of a business expert can help uncover self dealing. Using this procedure is convenient for the minority shareholder since the judge can oblige the company to pay for the expert's compensation, which is not the case for the generally applicable procedure providing for the appointment of a pre-trial court expert (so-called expertise in futurum) ${ }^{89}$ Italian law grants minority shareholders a similar right, but where serious irregularities in the company's management are found, the court may take further measures, such as convening the general meeting or even removing the directors. ${ }^{90}$

In Germany, AG shareholders holding $1 \%$ or an amount corresponding to $€ 100.000$ of legal capital (down from 10 percent/ $€ 1,000.000$ before the 2005 reform $^{91}$ ) may petition the court to appoint a special auditor. ${ }^{92}$ In a de facto

86 For Germany, see $\$ 92$ InsO (stipulating that claims common to all creditors must be persued by the insolvency administrator); for Italy, see supra note 84; for France, see Article L. 652-3, French C. com. (sums recovered under Article L. 652-1 are distributed to creditors according to their ranking). Of course, if no bankruptcy proceeding follows insolvency, e.g. because, as under German law, assets are insufficient, or if the bankruptcy proceeding is closed and a creditor has not been satisfied in full, she will have a direct claim toward the directors for damages stemming from violations of their duties.

87 BGH 6.6.1994, II ZR 292/91, BGHZ 126, 181. See e.g. Kalss et al, supra note 70, at 116. For Italy, see Article 2485(1), Italian C.c. For the different regime in France see Article L. 632-1, French C. Com.

88 Article L. 225-231, French C. Com.

89 Article 145, French NCPC (New Code of Civil Procedure).

90 Article 2409, Italian C.c.

91 The so-called UMAG, supra note 55.

$92 \$ 142 \mathrm{II}$ AktG. 
group, there is no such threshold. Any individual shareholder may petition a court to appoint a special auditor if the statutory auditor or the supervisory board found irregularities, or if the management board itself declares that disadvantageous transactions were not compensated for. ${ }^{93}$ The purpose of the special audit is to bring to light evidence that might help in a potential suit against board members. ${ }^{94}$

\section{Nullification of sharebolder and board meeting resolutions}

In all three jurisdictions, shareholders have the right to challenge in court the validity of shareholder resolutions, if they violate the company's bylaws or the law. ${ }^{95}$ Voting behavior violating either rules or standards of conduct for shareholders (such as the duty of loyalty in Germany or the "abuse of majority" prohibition in France and Italy) is considered a violation of the law and may result in nullification.

Challenges to the validity of shareholder resolutions have traditionally been used as a shareholder remedy in Italy and Germany, because it is an effective bargaining tool against the company and its dominant shareholders. In fact, thanks to the possibility of obtaining a court order requiring directors not to execute the transaction, shareholders might block important transactions. ${ }^{96}$ Of course, it is often alleged that the power to block transactions also allows minority shareholders to blackmail companies into lucrative settlement agreements. That explains why in 2003 Italy amended the relevant Code provisions so as to reduce minority shareholders' bargaining power vis-à-vis the company. Among other changes, ${ }^{97}$ it restricted standing to sue to shareholders representing at least 5 percent or 0.1 percent of the shares (for non-

$93 \$ 315$ AktG.

94 Uwe Hüffer, Aktiengesetz ( $7^{\text {th }}$ ed. 2006), $\$ 142$, note 1.

95 For Germany, see $\$ \$ 241-257$ AktG. For France, see Article L. 225-252, French C. com. For Italy see Articles 2377-2379-ter, Italian C.c. See also Article 2373 (declaring resolutions approved by the vote of a shareholder who has an interest in conflict with the corporate interest voidable if they are harmful to the company). For Srls see Article 2479ter, Italian C.c. (granting a similar cause of action to any shareholder of Srl).

96 See Article 2378(3) Italian C.c. (plaintiffs may petition court to order directors not to execute the resolution). For Germany, see Hüffer, supra note $94, \$ 243$, note 66 . The trial court may issue an injunction halting the registration in the register of companies under $\$ \$ 935-945 \mathrm{ZPO}$.

97 See also infra note 101. 
listed and listed companies respectively).$^{98}$ Shareholders representing a lower fraction of shares may only sue the company for damages suffered as a consequence of the resolution's illegality. ${ }^{99}$ But they may do so only within 90 days from the general meeting. ${ }^{100}$

To the same end, Germany recently introduced a so-called "clearance procedure" (Freigabeverfabren), which allows the court to allow an increase or reduction of capital or an agreement to enter a contractual group to proceed if the suit is patently baseless, or if the alleged violations of the law are less onerous to the firm and its shareholders than the disadvantage of the transaction grounding to a halt. ${ }^{101}$ Unlike Italy, Germany did not go in the direction of requiring a minimum ownership threshold for challenges of shareholder resolutions. In France, there are no restrictions to standing to sue either.

Of course, the relevance of nullification suits as remedies against self-dealing by large shareholders hinges on the requirement of a shareholder vote on the particular self-dealing transaction. Generally, the number of decisions that must be submitted to the shareholder meeting by law is said to be greater in continental Europe than in the US. ${ }^{102}$ However, this may still not be enough to enable minority shareholders to tackle self-dealing in all cases. Typically,

98 Or the lower percentage provided for by the bylaws: Article 2377(3), Italian C.c. Since 1975 a 5 percent threshold has prevented (and still prevents today) small shareholders of listed companies from challenging the validity of resolutions approving annual accounts of listed companies on the grounds that they fail to conform with the provisions governing the preparation thereof, provided that the company's auditor has judged the accounts to be consistent with such provisions and generally accepted accounting principles. See Enriques, supra note 17, at 785. See also infra, text accompanying note 110 .

99 Article 2377(4), Italian C.c. See e.g. Luca Enriques \& Andrea Zorzi, 'Spunti in Tema di Rimedi Risarcitori Contro l'Invalidità delle Deliberazioni Assembleari', 2006/I Rivista del Diritto Commerciale e del Diritto Generale delle Obbligazioni 1, 22-25. Italian legal scholars tend to deny that minority shareholders may also sue majority shareholders for such damages. See e.g. Sacchi, supra note 73, at 163-65.

100 Article 2377(6), Italian C.c.

$101 \$ 246 a \mathrm{AktG}$, as amended by the UMAG (supra note 55) of 2005. Similarly, the Italian corporate law reform of 2003 specified that the judge has to decide upon a petition to block a shareholder resolution by comparing the prejudice the plaintiff would suffer following execution with the prejudice the company would suffer from not executing the resolution.

102 See Cools, supra note 1, at 739-741. See also Lele and Siems' shareholder protection index, at http://www.cbr.cam.ac.uk/pdf/Lele-Siems-Shareholder-Index-Final1.pdf (analyzing the powers of the shareholder meeting in France, Germany, the UK, the US, and India following a leximetrics approach). 
only major reconfigurations of the corporate structure must be subject to a vote, including mergers and demergers. However, the well-known German Holzmüller doctrine illustrates important limitations. Under a seminal case decided by the German BGH in $1982^{103}$, a shareholder vote is required if a sale touches upon the core of the company's business. ${ }^{104}$ The doctrine was apparently narrowed by the BGH in the Gelatine ${ }^{105}$ decision of 2004 . While the precise extent of the Holzmüller doctrine is still not entirely clear, ${ }^{106}$ the number of cases submitted to the shareholder meeting may be dwindling down as a result of Gelatine.

If shareholders lack standing to sue in order to tackle a self-dealing transaction, they may resort to what one of us has elsewhere dubbed as "ostensible" shareholder litigation, that is, suits by which shareholders, "lacking the standing to ask a court to judge the specific behavior that purportedly harmed them, ... challenge other courses of action or decisions," 107 thus hoping "to strengthen their bargaining position against insiders." 108 For example, minority shareholders may attempt to nullify the annual "discharge" (Entlastung, quitus) of directors, which is of only very limited legal significance, ${ }^{109}$ or they may seek to nullify the shareholder meeting's approval of the firm's annual accounts. ${ }^{110}$

Shareholders may also have standing to sue in order to obtain nullification of a company's board resolutions. This is the case in France with respect to selfdealing transactions for which the ex ante authorization of the board of directors was not obtained, ${ }^{111}$ whereas in Italy minority shareholders may not challenge the validity of board resolutions taken in violation of the similar Italian rules on directors' interests: only dissenting directors and the board

103 BGH 25.2.1982, II ZR 174/80, BGHZ 83, 122.

104 See Marc Loebbe, 'Corporate Groups: Competences of the Shareholders' Meeting and Minority Protection - the German Federal Court of Justice's recent Gelatine and Macrotron Cases Redefine the Holzmüller Doctrine', 5 German L. J. 1057, 1061 (2004).

105 BGH 26.4.2004, II ZR 155/02, BGHZ 159, 30 (finding that "unwritten competences of the shareholder meeting are only recognized exceptionally and within narrow boundaries").

106 See Loebbe, supra note 104, at 1075-76.

107 Enriques, 'Do Corporate Law Judges Matter?', supra note 17, at 773.

108 Id., at 789.

109 See e.g. OLG Stuttgart, 11.08.2004, 20 U 3/04, DB 2004, $2094=$ NZG 2004, 966 = AG $2005,94$.

110 This is relatively often the case in Italy. See Enriques, 'Do Corporate Law Judges Matter? Some Evidence from Milan', supra note 17, at 785.

111 CA Amiens, $1^{\text {st }}$ December, 1966, Recueil Dalloz 1967, p. 234, n. Dalsace. 
of auditors may. Individual shareholders in Italy may only challenge the validity of board resolutions directly infringing their individual rights toward the corporation, such as when the board violates a shareholder's pre-emption right when issuing new shares. ${ }^{12}$ In Germany, shareholders cannot challenge board resolutions. ${ }^{113}$

\section{Nullification of conflict of interest transactions}

Under Italian law, if the person acting in the name of the corporation in a selfdealing transaction can be deemed to have a conflict of interest herself, possibly for her relationship with the dominant shareholder, then the transaction is voidable according to general agency law principles. The same is true if a board resolution is taken with no prior disclosure of a director's direct or indirect interest ${ }^{114}$ or by her vote or without motivation, provided that the transaction is harmful to the corporation. However, in either case only the corporation itself has standing to sue, so that cases of this kind are usually brought in two cases. First, such suits may be brought opportunistically, to renege on a company's obligations, for instance when it had accepted to become the guarantor of a related company's debt toward a bank. Second, bankruptcy trustees may bring such suits in order to disallow a claim. ${ }^{115}$

In France, self-dealing transactions are voidable if they were not subject to a vote by the board of directors and they have a detrimental effect on the company, ${ }^{116}$ or if the interested shareholder or director exercised her vote at the board of directors' meeting authorizing them, no matter whether the contract would have been authorized without her vote. ${ }^{117}$ In both cases, the action can be brought by the company itself or by a shareholder acting individually.

112 See e.g. Gianluca Guerrieri, 'Articolo 2388', in 1 Il Nuovo Diritto Societario 724, 738-39 (Alberto Maffei Alberti ed. 2005).

113 However, the annual accounts approved by the management board and the supervisory board (no shareholder resolution is required if the two boards consent) may be void under severe circumstances. See AktG $\$ 256$.

114 See supra text accompanying note 16.

115 Until 2003, it was possible to renege on one's obligations also by invoking the ultra vires doctrine, under which the company's acts that went beyond the company's activity ("oggetto sociale") as identified in the memorandum of association were without effect toward the company, provided that absence of good faith by the counterparty was proven. See Article 2384-bis Italian C.c. (repealed by the 2003 corporate law reform).

116 Article L. 225-42 French C. com.

117 CA Aix-en-Provence, 15 May 1990, Dr. Sociétés, 1991 n 279. 
Similarly, under German civil law, a contract may be voidable under principles of agency law if the agent colludes with a third party and abuses her power to the detriment of her principal. ${ }^{118}$ Furthermore, in cases where a board member lacked the authority to bind the firm (see supra section II.1.), the transaction is void.

Finally, if the company goes bankrupt, the bankruptcy trustee may challenge self-dealing transactions by invoking fraudulent conveyance provisions. Provided that such transactions have been entered into in the proximity of insolvency, the court can declare them without effect. ${ }^{119}$ At least in Germany, the practical significance of fraudulent conveyance provisions with respect to self-dealing transactions in corporations is dwarfed by the concealed distributions doctrine (which will also apply to the same cases), ${ }^{120}$ as vulnerability periods for fraudulent conveyance are very short except in cases of intentional hindrance of creditors ${ }^{121}$ or transactions without consideration. ${ }^{122}$

\section{Summary}

Our results regarding remedies are probably not new to continental European scholars, but they are of interest for the comparative debate: first, liability suits remain rare for reasons that may rather be due to aspects procedural

\section{Supra note 19.}

119 For Italy, see Articles 64 and 67, Royal Decree No. 267 of 16 March 1942, as amended (respectively providing for a vulnerability period of two years prior to the opening of bankruptcy proceedings in the case of gratuitous transactions, and for a vulnerability period of one year or six months for other transactions, depending on their type, on whether they are at an undervalue, and on the counterparty's knowledge of the company's insolvency or absence thereof). For France, see Art. L. 632-1 French C. com. (the vulnerability period is 18 months prior to the opening of the bankruptcy proceedings for all transactions other than gratuitous ones, for which the vulnerability period can be up to two years). In Italy, intra-group transactions are treated more severely than others under fraudulent conveyance law. For companies other than medium and small ones entering into bankruptcy, the relevant period for the challenge of intra-group transactions is five or three years instead of one year and six months for other transactions. See Article 91, Legislative Decree No. 270 of 8 July 1999 and Article 6, Law Decree No. 347 of 23 December 2003 (both applying to companies that have entered the special bankruptcy proceeding that the law provides for companies crossing certain size thresholds in terms of number of employees and amount of outstanding debt).

120 Supra section II.2.

$121 \rrbracket 133$ InsO: ten years.

$122 \$ 134$ InsO: four years. Other transactions hindering creditors must have been entered into three months before the debtor became insolvent ( $\$ 132 \mathrm{InsO}$ ). 
law, such as the absence of contingency fees and of a discovery procedure, than corporate law. Second, nullification suits appear to be quite common. However, we have seen that the possibility of such suits rests on the existence of shareholder decision rights.

\section{Criminal sanctions applicable to tunneling}

Each of the three jurisdictions provide for criminal sanctions against abusive self-dealing. In France, the main criminal law tool against self-dealing is the provision against abuse of corporate assets (abus de biens sociaux). ${ }^{123}$ It punishes, among others, board chairmen, directors or managing directors of a public limited company or a limited liability company (SARL) who "use the company's property or credit, in bad faith, in a way which they know is contrary to the interests of the company, for personal purposes or to favor another company or undertaking in which they have a direct or indirect interest." 124 The penalty is a prison term of up to five years (with no minimum).

In France, the minority shareholder, acting derivatively in the name of the company (action sociale ut singuli), can initiate a criminal prosecution by filing a criminal complaint (plainte avec constitution de partie civile) with the Dean of the Examining magistrates (Doyen des Juges d'Instruction) of the Civil first degree court (Tribunal correctionnel). In order for the complaint to be admissible, it is enough that the circumstances which gave rise to the complaint allow the examining magistrate to consider "possible" the existence of the damage to the company and the link with the alleged abuse of corporate assets. ${ }^{125}$ Case law has long made it clear that the examining magistrate has a duty to investigate, as long as she deems this undemanding standard to be met. ${ }^{126}$ This remedy is very attractive for minority shareholders since the examining judge holds the ability to access documents, and at no or very little cost for the plaintiff shareholder. As a consequence, criminal prosecutions for abus de biens sociaux are relatively frequent in France.

Some statistics as to the effectiveness of the abus de biens sociaux are available. According to the French Department of Justice, there have been be-

123 Article L. 242-6, French C. Com.

$124 \mathrm{Id}$.

125 Cass. Crim., 5 November 1991, Société Industrielle et Financière Bertin, Rev. Sociétés 1992, p. 91, n. B. Bouloc. See also Eva Joly and Caroline Joly-Baumgartner, 'L'abus de biens sociaux à l'épreuve de la pratique 288' (2004).

126 Cass. Crim., 8 December 1906, Laurent Atthalin, S. 1907.1.377 n. Demogue, D. 1907.1.207. 
tween 416 and 480 convictions for abus de biens sociaux in France every year from 2000 to $2006 .{ }^{127}$ Unfortunately, the statistics from the French Department of Justice are not so precise as to pinpoint whether the convictions for abus de biens sociaux include a prison sentence without stay of execution (prison ferme). However, the figures for criminal convictions relating to company law in general, which include abus de biens sociaux, indicate that in the same years between 848 and 1075 decisions were taken, of which between $17 \%$ to $22 \%$ included a jail sentence without stay of execution ${ }^{128}$. If these 2000-2006 general statistics are applied to the convictions for abus de biens sociaux, this would mean that an average of around $20 \%$ of convictions for abus de biens sociaux includes a jail term without a stay of execution ${ }^{129}$. This would translate into 83 to 96 convictions a year between 2000 and 2006..$^{130}$

French courts have created a special doctrine on abuse of corporate assets within groups (the so-called Rozenblum doctrine). ${ }^{131}$ This doctrine admits a "group defense" under certain conditions. First, there must be a group characterized by capital links between the companies. Second, there must be strong, effective business integration among the companies within the group. Third, the financial support from one company to another company must

127 Annuaire Statistique de la Justice, Edition 2006, p. 189, available at http://www.justice. gouv.fr/. Most criminal convictions relating to company law are for abus de biens sociaux and banqueroute (criminal bankruptcy).

128 Annuaire Statistique de la Justice, Edition 2006, p. 189, available at http://www.justice. gouv.fr/.

129 This is a significant increase compared to figures for 1997 to 1999 were this ratio, specifically established for abus de biens sociaux, was only between $5 \%$ and $15 \%$. Eva Joly and Caroline Joly-Baumgartner, L'abus de biens sociaux à l'éprewve de la pratique 280 (2004).

130 For various reasons, a conviction to a prison term without stay of execution does not mean that those convicted for abus de biens sociaux really end up in jail. Although there are no specific statistics available, in 2001 the French Department of Justice published a study on the execution of criminal convictions for all types of misdemeanor (délits), which therefore include abus de biens sociaux but also non-economic offenses. The study showed that only $54.5 \%$ of prison sentences without stay of execution for misdemeanor actually led to imprisonment. However, only $12 \%$ of the jail sentences without stay of execution were not executed without a valid reason (i.e. appeal, pardon, flight from justice etc.). Infostat Justice, juillet $2005, \mathrm{n}^{\circ} 83$, 'L'exécution des peines d'emprisonnement ferme', available at www.justice.gouv.fr/index. php? rubrique $=10054 \&$ ssrubrique $=10057 \&$ article $=11820$

131 See Trib. Corr. Paris, 16 May 1974, Soc. Saint-Frères, D. 1975, p. 37, Rev. Sociétés 1975, p. 657, n. B. Oppetit, JCP éd. E. 1075, II-11816, p; 381; Court of cassation, Criminal Chamber, 4 February 1985, Rozenblum and Allouche, D. 1985, p. 478, n. D. Ohl, I-639, JCP 1986, II-20585, n. W. Jeandidier, Rev. Sociétés 1985, p. 648, n. B. Bouloc. 
have an economic quid pro quo and may not break the balance of mutual commitments between the concerned companies. Fourth, the support from the company must not exceed its possibilities. In other words, it should not create a risk of bankruptcy for the company. ${ }^{132}$

In Germany, the criminal code punishes Untreue (disloyalty), which occurs when a person authorized to dispose over someone else's property or to bind another person abuses her authority to do so, or when a person subject to a duty to attend to someone else's financial interests violates the duty, and when this results in a disadvantage to the other person. ${ }^{133}$ Normally, the maximum penalty is five years, which may increase to 10 years in severe cases. ${ }^{134}$ Both members of the management board and the supervisory board may be subject to the provision. ${ }^{135}$ The statute is quite broad, even excessive risk-taking may result constitute Untrene, ${ }^{136}$ as can private benefits of control by managers and board members. ${ }^{137}$ It also applies to directors of a controlling firm in a corporate group with regard to the controlled firm's property. ${ }^{138}$ In general, directors are not criminally liable under this statute if the firm's sole shareholder agrees with the transaction or if it is approved in a shareholder meeting. ${ }^{139}$ However, directors and others may still be liable under criminal (and civil) law when the transactions puts the company's existence at risk affects the firm's legal capital. ${ }^{140}$

132 See Marie-Emma Boursier, 'Le Fait Justificatif de Groupe dans l'Abus de Biens Sociaux: Entre Efficacité et Clandestinité', Revue des Sociétés 2005, p. 273.

$133 \$ 266$ I StGB.

$134 \$ 266$ II StGB (referring to $\$ \$ 243$ II and 263 III StGB).

135 See e.g. Herbert Tröndle \& Thomas Fischer, Strafgesetzbuch (54 th ed. 2007), $\$ 266$, comment 54a.

136 E.g. Tröndle \& Fischer, id., $\$ 266$, comments 42-45a; Jürgen Seier, 'Die Untreue ( $\$ 266$ StGB) in der Rechtspraxis', in Bocbumer Beiträge zu Aktuellen Strafrechtstbemen 145, 151-152 (Klaus Bernsmann \& Klaus Ulsenheimer eds. 2003).

137 Seier, id. at 147-148 (referring to cases regarding the purchase of expensive paintings by the CEO as well as travel expenses of supervisory board members of governmentowned utility firms, where the standard seems to be particularly strict).

138 BGH 17.9.2001, II ZR 178/99, BGHZ 149, 10 (finding in favor of liability of the controlling [in this case only] shareholder to the bankrupt controlled company on the basis of a violation of $₫ 266$ StGB); BGH 13.5.2004, 5 StR 73/03, BGHSt 49, 147 (affirming the possibility of a criminal conviction in the same case).

139 BGH 21.12.2005, 3 StR 470/04, BGHSt 50, 331 = AG 2006, $110=$ JZ 2006, 560. However, since voting behavior by majority shareholders is subject to judicial review under the duty of loyalty, minority shareholders could seek to have the resolution nullified if it is harmful.

140 BGH 13.5.2004, supra note 138. See e.g. Holger Fleischer, 'Konzernuntreue zwischen Straf- und Gesellschaftsrecht: Das Bremer Vulkan-Urteil', 2004 Neue Juristische Wochenschrift 2867, 2869. This case was decided with regard to a $\mathrm{GmbH}$. 
The Federal Criminal Police Office (Bundeskriminalamt) reports 10,385 cases of Untrene for 2006 and 12,032 for 2005. ${ }^{141}$ However, this data aggregates all kind of Untrene cases, a small proportion of which (if any) reasonably involves dominant shareholders' self-dealing in public corporations. ${ }^{142}$ Furthermore, it includes all cases that were brought to the attention of the police, among which more than $98 \%$ are reported as solved. That, however, does not necessarily mean that they resulted in criminal prosecution and conviction.

A recent case of Untrene made headlines. In the Mannesmann trial, following a takeover battle against a hostile bid by Vodaphone, the supervisory board granted an "appreciation award" to Mannesmann's outgoing managing directors with the approval of Vodaphone's largest shareholder. ${ }^{143}$ The case ultimately did not result in a criminal conviction, but in the payment of a fine as result of a settlement. Other notable cases where the directors of an AG were prosecuted have related to unsecured lending within a corporate group (both firms later went into bankruptcy) ${ }^{144}$ or corporate donations. ${ }^{145}$ The practical significance of Untreue has risen in recent years. ${ }^{146}$ It is often criticized by legal scholars as overly broad and unclear, particularly in the context of business activity, where anything considered misconduct by courts can potentially result in a conviction. ${ }^{147}$

141 Bundeskriminalamt, Polizeiliche Kriminalstatistik 2006, 38 (54th. ed. 2006), available at http://www.bka.de/pks/pks2006/download/pks-jb_2006_bka.pdf (last visited Sept. 23, 2007).

142 The only subtype in the statistics relates to investments (Untreue bei Kapitalanlagegeschäften), of with 345 and 545 cases are reported for 2006 and 2005 respectively, for which no definition is given. Furthermore, An aggregate figure of 18324 and 11064 cases of fraud and disloyalty regarding shares and investments („Betrug und Untreue i.Z.m. Beteiligungen und Kapitalanlagen") is given (again for 2006 and 2005), almost all of which are reported as solved (Bundeskriminalamt, id. at 232).

143 BGH 21.12.2005, supra note 139 (finding that the "appreciation award" constituted Untreue). For an analysis of the decision, see Stefan Maier, 'A Close Look at the Mannesmann 'Trial', 7 German L. J. 603 (2006); Stephan Harbarth \& Florian Kienle, 'Director Compensation Under German Law and the Mannesmann Effect', 3 Eur. Company L. 90, 94-95 (2006); Franklin A. Gevurtz, 'Disney in a Comparative Light', available at http://ssrn.com/abstract $=965596$.

144 BGH 22.11.2005, 1 StR 571/04, 2006 Neue Juristische Wochenschrift 453.

145 BGH 6.12.2001, 1 StR 215/01, 2002 Neue Juristische Wochenschrift 1585.

146 Seier, supra note 136, at 145-146 (suggesting that the provision has experienced a boom in recent years).

147 E.g. Seier, id. at $150,153-156$ (arguing that $\$ 266$ StGB, as interpreted by the courts, is unconstitutional); Holger Fleischer, 'Das Mannesmann-Urteil des Bundesgerichtshofs: Eine aktienrechtliche Nachlese', 59 Der Betrieb 542, 544 (2006) ("\$266 always fits"); see also Hans Dahs, ' $\$ 266$ - allzuoft missverstanden', 2002 Neue Juristische Wochenschrift 272, 273 (suggesting that the provision was introduced in 1933 to prosecute political opponents). 
In Italy, directors and general managers are criminally liable for infedeltà patrimoniale (disloyalty) if, "having a conflict of interest with the corporation, and with the purpose of making an unfair profit or of letting someone else make an unfair profit, they enter into, or take part in decisions relating to, transactions on corporate assets, thereby intentionally harming the corporation." ${ }^{148}$ In the context of corporate groups, the provision accepts the idea of "compensatory advantages:" while the crime requires intent to gain or let others gain an "unjust profit", a profit deemed to be made by the group of companies is not unjust, whenever the company's damage is offset by advantages, whether actual or even only prospective, deriving from the relevant company's being part of the group. ${ }^{149}$

The prison term ranges from a minimum of six months to a maximum of three years. However, criminal trials in Italy take a long time, while statute of limitation terms for the crime are short and, with due qualifications, also run during the trial; further, a criminal law provision allowing judges to suspend the execution of criminal convictions to prison for a term of up to two years in case of first-time offenders is widely applied. As a consequence, it is extremely unlikely that any director or manager will ever go to jail for such a crime. ${ }^{150}$

Public prosecutors can only start prosecutions for this crime if the victim files a charge against the directors. ${ }^{151}$ Until recently, the common view was that shareholders were not victims of the crime, an abuse of corporate assets only harming directly the corporation, and shareholders' indirect damage being irrelevant for criminal law purposes. ${ }^{152}$ However, a recent Supreme Court case included shareholders among crime victims, ${ }^{153}$ so that now they may file a charge and also petition the criminal court for a conviction to damages suffered qua shareholders from the disloyalty (i.e. their pro rata share of the total damage caused by the self-dealing transaction to the corporation).

For listed companies, a recent provision punishes directors who fail to disclose to other board members their interest in a transaction, if such a failure to disclose causes damages to the corporation or other parties. The prison term ranges from a minimum of one year to a maximum of three. ${ }^{154}$

148 Article 2634, Italian C.c.

149 Article 2634(3), Italian C.c.

150 See Enriques, supra note 16, at 477 (with reference to the criminal provision, in force between 1942 and 2002, forbidding directors to vote in conflict-of-interest transactions between 1942 and 2000).

151 Article 2634(4), Italian C.c.

152 See Cass. 17 January 2003, n. 20267 in 2003 Fisco 4900.

153 Cass. 16 June 2006, No. 37033.

154 Article 2629-bis, Italian C.c. See also supra note 148. 
Finally, all three countries punish banqueroute, bancarotta fraudolenta, and Bankrott, a crime that includes asset diversion, whether through self-dealing or otherwise, in insolvent corporations or in corporations that are driven to insolvency as a consequence of such diversion. ${ }^{155}$

To conclude, we can say that criminal law plays a different role in the three jurisdictions. While in Italy it only effectively punishes self-dealing in the context of bankruptcy, ${ }^{156}$ criminal prosecution of Untreue in Germany is also possible outside bankruptcy. Finally, criminal enforcement is of particular importance in France, where minority shareholders can bring a "derivative" criminal claim on behalf of the company. This is particularly attractive as the examining magistrate has much better access to evidence than shareholders.

\section{Stock dilution}

With stock dilution, the ultimate outcome is similar as in cases of tunneling, i.e. minority shareholders' value is depressed, but the process is quite different. While tunneling happens through business transactions of the corporation, majority shareholders (i.e. the company's board on their input) have to initiate an amendment to the corporate charter in continental Europe in order to dilute the minority's stock. The first type of possibly stock-diluting transaction are increases of capital, and most of all recapitalizations following losses, where the minority's shares are diluted if the majority shareholder contributes new capital to the firm at an undervalue.

Parent-subsidiary mergers and squeeze-outs are the second important form of self-dealing discussed here. Minority shareholders of the subsidiary may be deprived of their share of firm value if the exchange ratio between shares of the parent and the subsidiary is unfair to the latter's shareholders, i.e. when the estimate of the subsidiary's value is too low.

155 For France, see Article L. 654-2 $2^{\circ}$, French C. Com. (providing prison sentences of up to five years); for Germany see StGB $\$ \$ 283,283$ a (providing prison sentences of up to two, five or ten years depending on the severity of the case); for Italy, see Articles 216 and 223, Royal Decree No. 267, of 16 March 1942 (punishing directors and general managers, but construed as applying also to shadow directors. See e.g. Cass., 12 July 2004, 2005 Impresa 501; the prison term ranges from a minimum of three years to a maximum of ten years; the longer prison terms imply that the risk of going to jail after being convicted for such a crime are much higher, because the statute of limitation term is longer and suspension of the execution of the conviction is less likely: see supra note 148).

156 See supra notes $148 \& 155$. 
May be because the danger resulting from these mechanisms is quite obvious, all three jurisdictions address the issue mostly with rule-based safeguards.

\section{Recapitalizations}

All three jurisdictions, with due qualifications and exemptions, provide for safeguards against stock dilution in the form of targeted issues of new shares. Following the Second Directive, all three countries grant shareholders a preemption right over new issues of shares. ${ }^{157}$ However, the shareholder meeting can resolve to exclude such right with regard to specific new issues of shares. Typically, specific reporting requirements must be followed. ${ }^{158}$ In Germany, courts have required an objective reason, ${ }^{159}$ which could be given e.g. when the company intends to recapitalize following a period of severe losses, and struck down shareholder meeting resolutions based on inadequate reasons. Similarly, Italian law requires that the decision not to grant pre-emptive rights be not only justified, but also "necessary to attain the company's interest." ${ }^{160}$ Under French law, the board of directors must provide a report giving the reasons for the resolution as the Second Company Law Directive requires, ${ }^{161}$ but, other than in Germany and Italy, there is no substantive judicial review on whether the exclusion of preemptive rights is justified.

\section{Mergers and squeezeouts}

The laws of all three countries provide procedural and disclosure requirements that have been set forth in the Third Directive for public corporations. ${ }^{162}$ Mergers are subject to a shareholder meeting resolution ${ }^{163}$ following

157 Second Directive, art. 29(1). The second directive requires preemptive rights only in cases of cash contributions.

158 Article L. 225-135, French C. Com.; $\$ 186$ IV AktG, with respect to which courts have required an objective reason; Article 2441, Italian C.c.

159 BGH 13.3.1978, II ZR 142/76 (“Kali+Salz”), BGHZ 71, 40; BGH 19.4.1982, II ZR 55/81 ("Holzmann") BGHZ 83, 319.

160 Article 2441, Italian Civil Code. Leaving aside the doctrinal intricacies of this wording, courts tend to engage in a substantial review of the resolution's consistency with the corporate interest in applying the provision. See Federico M. Mucciarelli, Interesse sociale ed esclusione del diritto d'opzione: spunti di riflessione sulla logica dell'argomentazione del giudice, 2002 Giurisprudenza Commerciale I/455, I/459-63.

161 Article L. 225-135, French C. Com. The relevant section is art. 29(4) of the Second Directive. The equivalent provision in Germany is $\$ 186$ IV AktG. For Italy, see Article 2441(6) C.c.

162 Third Council Directive 78/855/EEC of 9 October 1978 based on Article 54 (3) (g) of the Treaty concerning mergers of public limited liability companies, 1978 O. J. (L 295) 36-43.

163 Third Directive, Article 7. 
a report by the board of directors which must explain "the draft terms of merger and set [...] out the legal and economic grounds for them, in particular the share exchange ratio." 164 According to the Directive, "[o]ne or more experts, acting on behalf of each of the merging companies but independent of them, appointed or approved by a judicial or administrative authority, shall examine the draft terms of merger and draw up a written report to the shareholders." 165 In the report, "the experts must in any case state whether in their opinion the share exchange ratio is fair and reasonable." 166

In Italy, shareholders can challenge the validity of the merger resolution if they have the minimum stake required in general for such challenges. ${ }^{167}$ However, once the merger contract has been deposited in the companies register, the court may not declare the resolution void and shareholders may only obtain damages from the company and its directors, e.g. if the exchange ratio is unfair. ${ }^{168}$

Squeeze-out or cash-out mergers are not allowed under Italian law. The squeeze-out remedy is only available to majority shareholders of listed companies having crossed the threshold of 98 (soon to be 95) percent of the shares following a bid for all the outstanding shares. ${ }^{169}$

In France, the decision to merge, and indirectly the exchange ratio, cannot be challenged unless there is an abuse of majority, which is difficult to prove. Minority shareholders can also sue the expert in case of mistake, but there are very few cases. Besides, a major flaw in the protection of minority shareholders is that if it is the subsidiary that incorporates its parent company, the parent company, despite its obvious conflict of interest, may vote on the merger resolution, which is not the case if the parent incorporates the subsidiary. However, for listed companies, the French securities regulator can force a controlling shareholder to initiate a buyout offer (offre publique de retrait) when she has decided to merge the controlled company into the controlling company. ${ }^{170}$ This provision can be used by the securities regulator, for $\mathrm{ex}^{-}$ ample, if it deems the exchange ratio to be unacceptable.

164 Third Directive, Article 9.

165 Third Directive, Article 10.

166 Id.

167 See supra section III.3.

168 Article 2504-quater, Italian C.c.

169 Article 111 Legislative Decree No. 58 of 25 February 1998.

170 Article 236-6 $2^{\circ}$, Financial Markets Authority (Autorité des Marchés Financiers) General Regulation. 
Finally, squeezeouts (retrait obligatoire) are only possible in listed companies. ${ }^{171}$ The majority shareholder needs to hold more than $95 \%$ of the capital or of the votes following a buyout offer (offre publique de retrait).

In Germany, the unfairness of the exchange ratio may not be the ground for lawsuits seeking to nullify the merger resolution by shareholders of the company whose assets are transferred. ${ }^{172}$ In this situation, they have a claim to compensation in cash. ${ }^{173}$ If the compensation is too low, they may petition a court to set the amount (under the award specification procedure described below). ${ }^{174}$ Equivalent rules apply to transformations into a different legal form, ${ }^{175}$ squeezeouts (which can be requested upon the petition of a $95 \%$ shareholder $)^{176}$ and organizational integrations of one corporation into another. ${ }^{177}$ The consequence of these rules is that it is considerably hard for minority shareholders to block a merger. The idea is that the transaction should not be stopped by a (possibly frivolous) shareholder suit. Finally, members of the management and supervisory boards may be subject to liability. ${ }^{178}$

As hinted before, the creation of a contractual group has similar consequences to those of a merger. Hence, there are similar safeguards as those regarding mergers, i.e. a control agreement requires the approval of a 75 percent supermajority of shareholders in the controlled company and in the controlling entity (if it is also an AG), ${ }^{179}$ and certain reporting and auditing requirements must be met. To compensate for these disadvantages, the controlling entity must also absorb losses made by the controlled corporation, ${ }^{180}$ and the control agreement must stipulate an annual payment to minority shareholders. ${ }^{181}$ Furthermore, a control agreement must give minority shareholders a right

171 Article L. 433-4, French Financial and Monetary Code.

$172 \$ 14$ II UnwG. By contrast, shareholders of the company to which the assets are transferred may seek nullification.

$173 \$ 15$ UmwG.

$174 \$ 34$ UmwG. See infra note 184 and corresponding text.

$175 \$ \$ 196,212$ UmwG.

$176 \$ \int 327 a, 327 f$ AktG.

$177 \$ 320 \mathrm{~b}$ AktG.

$178 \$ 25$ et seq UmwG.

$179 \$ 293$ AktG.

$180 \$ 302$ I AktG. It is unclear whether shareholders of the controlled entity may enforce this claim with a derivative action. See Hüffer, supra note 94, $\$ 302$, comment 20; but see Gerard Hertig \& Hideki Kanda, 'Related Party Transactions', in Reinier Kraakman et al., The Anatomy of Corporate Law 101, 125 (2004) (claiming that a derivative suit is possible). However, it is certain that directors of the controlled company have a duty to enforce this claim.

$181 \$ 304$ I, II AktG. 
to exit, i.e. the controlling entity must offer to purchase their shares for an adequate compensation consisting of shares of the controlling entity if it is an $A G^{182}$ or otherwise of cash. ${ }^{183}$ As in a merger, the shareholder resolution to accept the control agreement may not be void or nullified on the grounds that the annual compensation or the compensation for leaving the controlled firm is too low. However, shareholders may petition a court to stipulate an adequate compensation or share exchange ratio (so-called Sprucbstellenverfabren, or "award specification procedure"). ${ }^{184}$

\section{Summary}

As we have seen, there are specific mechanisms against stock dilution in all of the three countries, which are partly influenced by EC law. In the case of recapitalizations, at least in Italy and Germany shareholders may challenge the validity of the resolution approving a recapitalization on the ground of an insufficient "objective reason" for the exclusion of preemptive rights. In the case of mergers, scissions and squeezeouts, such a reason is not required to justify the transaction as such, but minority shareholders may obtain monetary compensation for an unfair exchange ratio.

\section{Conclusion: a research agenda}

The starting point for our overview of the three main continental European countries laws on self-dealing by dominant shareholders was the most recent law and finance study by LLSV, which focuses precisely on self-dealing laws. According to their scores, Italy and France display approximately the same quality of law, while Germany lags behind. Our overview makes no attempt to translate legal rules into scores. It shows, instead, that all three countries provide a large array of doctrines and remedies against self-dealing, some of them incidentally quite different from those familiar to English-speaking scholars. It is far from easy to tell what jurisdiction among the three has the most effective rules, and it is even harder to evaluate how well they fare compared to US or UK law. However, we have shown some peculiar features of the three countries' legal framework, which might at least reduce the per-

182 It is also possible to distribute shares in compensation if the controlling entity is a Kommanditgesellschaft auf Aktien (a limited partnership where the limited partners' membership rights are embodied in tradable shares).

$183 \rrbracket 305$ I-IV AktG.

$184 \$ 304$ III, $305 \mathrm{~V} \mathrm{AktG.}$ 
ceived gap between the Anglo-American framework and the continental European one. The German prohibition against concealed distributions has so far received little - if any - attention in the international debate regarding self-dealing. Similarly, the role of minority shareholders in the prosecution of abus de biens sociaux in France has so far been neglected. Finally, we have highlighted the importance of nullification suits in all three countries and especially in Germany and Italy, although recent reforms, in Italy more than in Germany, have cut the teeth of this remedy.

We have also shown that liability suits are permitted in all three countries, with France requiring no minimum holding to bring suit, and Germany and Italy doing the same in the crucial area of group law. However, it is well known that these suits remain rare compared to the US, even where there no minimum thresholds apply. As hinted above, the reason for the absence of private enforcement may rather be issues of procedural law, such as the absence of contingency fees and of a discovery procedure, for which the possibility to request the appointment of a special auditor does not seem to make up.

To evaluate the effectiveness of these legal frameworks to protect minority shareholder interests, empirical work focusing on the law in action is needed. While anecdotal evidence exists as to what extent and in which situation the doctrines and remedies we have identified are used in each of the three countries, there has been no systematic effort so far to categorize decisions and to find out under which circumstances self-dealing is likely to be sanctioned by the courts. A companion paper thus uses the legal framework outlined throughout this paper to proceed into such an investigation by looking at a large sample of published decisions from French, German and Italian courts. ${ }^{185}$ Although our focus is restricted to a low number of countries, we believe we can provide a more vivid and genuine picture of self-dealing laws in three main European jurisdictions.

185 Pierre-Henri Conac, Luca Enriques \& Martin Gelter, 'Enforcing Self-Dealing Constraints on Dominant Shareholders in Continental Europe', work in progress (on file with the authors). 